\title{
Cr(III)REMOVAL FROM AQUEOUS SOLUTION BYION EXCHANGE RESINS CONTAINING CARBOXYLIC ACID AND SULPHONIC ACID GROUPS
}

\author{
BERNABÉ L. RIVAS ${ }^{I^{*}}$, DANIELA V. MORALES ${ }^{1}, N_{\text {ALAN KABAY }}^{2}$, MAREK BRYJAK ${ }^{3}$ \\ ${ }^{1}$ Department of Polymers, Faculty of Chemistry, University of Concepción, Casilla 160-C, Concepción, Chile \\ ${ }^{2}$ Department of Chemical Engineering, Faculty of Engineering, Ege University, 35100 Izmir, Turkey \\ ${ }^{3}$ Department of Polymer and Carbon Materials, Faculty of Chemistry, Wroclaw University of Technology, Wroclaw, Poland
}

\begin{abstract}
Ion exchange resins based on the water-insoluble polymers poly(acrylamide-co-styrene sodium sulfonate) (P(AAm-co-ESS)), poly(2-acrylamide-2-methyl1-propanesulfonic acid-co-acrylicacid) (P(APSA-co-AAc)),poly(2-acrylamidoglycolic acid-co-2-acrylamide-2-methyl-1-propane sulfonic acid) (P(AAGA-coAPSA)), and poly(2-acrylamidoglycolic acid-co-4-styrene sodium sulfonate) (P(AAGA-co-ESS)) were synthesized by radical polymerization. These polymers were employed to remove $\mathrm{Cr}$ (III) from an aqueous solution. The optimum sorption parameters of amount of resin and sorption time were obtained through batchmode sorption tests. Following batch elution tests to identify the best eluting agent. Finally, the column-mode sorption/elution behaviors of ion exchange resins were studied.

The ion exchange resins exhibited excellent removal of $\mathrm{Cr}(\mathrm{III})$. The P(AAGA-co-APSA) resin exhibited 89.4\% removal, while P(AAGA-co-ESS) displayed $88.3 \%$, P(AAm-co-ESS) $86.8 \%$, and P(APSA-co-AAc) $89.3 \%$. The column-mode was studied by theP(AAGA-co-APSA) resingave a breakthrough capacity of $1.5 \mathrm{mg} \mathrm{Cr}(\mathrm{III}) / \mathrm{mL}$ resin in the first cycle. The elution efficiency was almost $100 \%$. The breakthrough capacity was $1.2 \mathrm{mg}$ Cr(III)/mL resin in the second cycle. The elution efficiency was $90.2 \%$ in the second cycle.
\end{abstract}

Keywords: ion exchange resins, chromium, removal, batch and column methods.

\section{INTRODUCTION}

There are several treatment methods to remove metal ions from water, such as chemical precipitation, extraction, coagulation, adsorption, membrane filtration, and ion exchange. Due to the low concentrations of metal ions in wastewaters and difficulties in handling large volumes of wastewater, many extraction processes become uneconomical. Precipitation requires the addition of relatively large amounts of chemicals. Applications using adsorption and ion exchange are preferable due to their well-established technologies for removal of metal ions in trace quantities from water. Notably, chelating ion exchange resins possess excellent selectivity in the separation of various metal ions from water. They can be synthesized easily and quickly by well-established procedures [1,2].The ion exchange resins are insoluble, crosslinked polymers that have functional groups such as sulfonic acid, carboxylic acid, phosphonic phosphinic acid, amide, amine, and quaternary ammonium. These functional groups can interact with the metal ions in the form of cations or anions via coordinative or ionic interactions [2].

There are many studies on metal removal using polymeric ion exchangers containing sulfonic acid as a functional group. Cavus et al. studied competitive heavy metal removal by poly(2-acrylamido-2-methyl-1-propane sulfonic acid-co-itaconic acid) to remove $\mathrm{Pb}(\mathrm{II}), \mathrm{Cu}(\mathrm{II})$, and $\mathrm{Cd}(\mathrm{II})$ ions from aqueous solutions with great retention [3].Urbano et al. studied the sorption properties of composites based on 2-acrylamido-2-methyl-1-propane sulfonic acid for $\mathrm{Pb}(\mathrm{II}), \mathrm{Cu}(\mathrm{II})$, and $\mathrm{Cd}(\mathrm{II})$. The addition of montmorillonite enhanced the mechanical properties of the ion exchange resin [4].Rivas et al. studied the metal ion removal properties of crosslinked poly(acrylamide-co-2-acrylamide2-methyl-1-propane sulfonic acid) for the extraction of $\mathrm{Pb}(\mathrm{II}), \mathrm{Hg}$ (II), $\mathrm{Cd}(\mathrm{II})$, $\mathrm{Zn}(\mathrm{II}), \mathrm{Al}(\mathrm{III})$, and $\mathrm{Cr}(\mathrm{III})$ metal ions from aqueous solution; they found that the adsorption capacity increased with $\mathrm{pH}$ [5]. Rivas et al. studied the retention of $\mathrm{Cu}(\mathrm{II}), \mathrm{Cd}(\mathrm{II}), \mathrm{Co}(\mathrm{II}), \mathrm{Hg}(\mathrm{II}), \mathrm{Ni}(\mathrm{II}), \mathrm{Zn}(\mathrm{II}), \mathrm{Cr}(\mathrm{III})$, and $\mathrm{Ag}(\mathrm{I})$ by poly(2acrylamido-2-methyl-1-propanesulfonic acid), poly(methacrylic acid), and poly[(2-acrylamido-2-methyl-1-propanesulfonic acid)-co-(methacrylic acid)] by the Liquid-phase Polymer-based Retention (LPR) technique [6].Bajaj et al. synthesized and characterized different copolymers of acrylonitrile-acrylic acids [7]. Rivas et al. also studied the synthesis and removal properties of $\operatorname{poly}(\mathrm{N}$-hydroxymethyl acrylamide-co-acrylic acid $)$ and poly $(\mathrm{N}$-hydroxymethyl acrylamide-co-acrylamidoglycolic acid) for $\mathrm{Cd}(\mathrm{II}), \mathrm{Cr}(\mathrm{III}), \mathrm{Zn}(\mathrm{II}), \mathrm{Pb}(\mathrm{II})$, and $\mathrm{Hg}(\mathrm{II})$. These researchers obtained promising results for the removal of $\mathrm{Pb}(\mathrm{II})$ (79\%) at pH 5 [8]. Urbano et al. studied the enhanced mechanical properties of polymer-clay ion exchange resins with poly(sodium 4-styrene sulfonate) and poly(2-acrylamido glycolic acid) and their metal ion retention for $\mathrm{Cd}(\mathrm{II})$, $\mathrm{Pb}(\mathrm{II}), \mathrm{Cu}(\mathrm{II}), \mathrm{Cr}(\mathrm{III})$, and $\mathrm{Al}(\mathrm{III})$. The results showed high efficiency over
$80 \%$ after only $1 \mathrm{~h}$ of contact [9]. Travas et al. studied the copolymerization of acrylamide-co-2-acrylamido-2-methyl-1-propane sulfonic acid by free radical polymerization [10]. Rivas et al. studied the synthesis and metal ion retention properties using the functional resin poly(4-styrene sulfonate-co-4vinylpyridine) and they found that the resin displayed an affinity of above $90 \%$ for $\mathrm{Cd}(\mathrm{II}), \mathrm{Pb}(\mathrm{II}), \mathrm{Cr}(\mathrm{III})$, and $\mathrm{Al}(\mathrm{III})$, for $\mathrm{Hg}(\mathrm{II})$ at $\mathrm{pH} 5$, while the highest retention was at $\mathrm{pH} 2$ [11]. Santander et al. studied the removal of $\mathrm{Cr}(\mathrm{VI})$ by a chelating resin containing N-methyl-D-glucamine [12]. Hasnat et al. studied a new approach to cation exchange kinetics [13].

Chromium is found mainly in the oxidation states of $\mathrm{Cr}(\mathrm{III})$ and $\mathrm{Cr}(\mathrm{VI})$. $\mathrm{Cr}(\mathrm{VI})$ compounds are highly oxidizing and toxic, whereas $\mathrm{Cr}$ (III) compounds are less toxic than those of $\mathrm{Cr}(\mathrm{VI})$. $\mathrm{Cr}$ (III) is beneficial and necessary for the human body and is involved in the metabolism of lipids and carbohydrates. $\mathrm{Cr}(\mathrm{VI})$ is a carcinogen and when inhaled causes lung cancer and dermatitis, while prolonged contact corrodes tissues. $\mathrm{Cr}(\mathrm{VI})$ is a bioaccumulative metal that affects growth [14]. $\mathrm{Cr}$ (III) is essential in glucose and lipid metabolism, but long term contact with $\mathrm{Cr}$ (III) can produce some skin allergies and cause respiratory problems. $\mathrm{Cr}$ (III) penetrates cell membranes to only a small extent but can react with DNA when it is used in cellular and subcellular systems. If it is present in the form of complexes with hydrophobic organic ligands, it can pass through cell membranes and produce gene mutations. On the other hand, there is no epidemiological or carcinogenic evidence for $\mathrm{Cr}$ (III) compounds [15].

Liet al. studied the kinetics and equilibrium of $\mathrm{Cr}$ (III) removal from aqueous solution by IRN-77 cation-exchange [16]. Gando-Ferreira et al. studied the application of ion exchange resins in the selective separation of $\mathrm{Cr}$ (III) from electroplating effluents using Diaion CR11-containing iminodiacetic acid groups [17]. Petruzzelli et al. studied Purolite C160 and Duolite A-7 for metal ion separation of $\mathrm{Cr}(\mathrm{III}), \mathrm{Fe}(\mathrm{III})$, and $\mathrm{Al}(\mathrm{III})$ [18]. Kocaoba et al. performed kinetic experiments with Amberlite IR 120 a strong cation exchange resin, for chromium removal,and they found that the system is controlled byboth particle and film diffusion [19]. Alguacil et al. studied Cr(III) removal using Amberlite 200 resin in batch and column tests, and they found that the Langmuir isotherm described the adsorption process well [20].

Our investigation group in the past already studied the synthesis and better performance ofP(AAGA-co-APSA), P(AAGA-co-ESS), P(AAm-co-ESS), and $\mathrm{P}(\mathrm{APSA}-\mathrm{co}-\mathrm{AAc})$ cationic ion exchange resins for remotion of metal ions from water, in comparison with the commercial resin Amberlite IRP-64[21, 22]. The aim of this research is to study the cationic ion exchange resins P(AAGA-co-APSA), P(AAGA-co-ESS), P(AAm-co-ESS), and P(APSAco-AAc) for the removal of $\mathrm{Cr}$ (III) from aqueous solution and to identify the optimal removal parameters using batch and column sorption-elution methods. 


\section{EXPERIMENTAL}

Materials

The reagents used to synthesize the ion exchange resins poly(acrylamideco-styrene sodium sulfonate) (P(AAm-co-ESS)), poly(2-acrylamide-2methyl-1-propanesulfonic acid-co-acrylic acid) (P(APSA-co-AAc)), poly(2acrylamidoglycolic acid-co-2-acrylamide-2-methyl-1-propane sulfonic acid) (P(AAGA-co-APSA)) andpoly(2-acrylamidoglycolic acid-co-4-styrene sodium sulfonate) (P(AAGA-co-ESS)) were acrylamide, the hydrated sodium salt of 4-styrenesulfonate acid, acrylic acid (99\%), 2-acrylamide-2-methyl-1propanesulfonic acid (99\%), 2-acrylamidoglycolic monohydrate acid (96\%), $\mathrm{N}, \mathrm{N}^{\prime}$-methylene-bis-acrylamide (99\%), and ammonium persulfate $(98 \%)$. All these reagents were purchased from Sigma-Aldrich. The reagents to study the removal properties were chromium (III) nitrate nonahydrate $(98 \%)$ and hydrochloric acid (37\%), both purchased from Merck.

\section{Synthesis of resins}

The process of copolymerization and characterization were already studied by our investigation group [21, 22]. The P(AAm-co-ESS), P(APSA-co-AAc),

a)

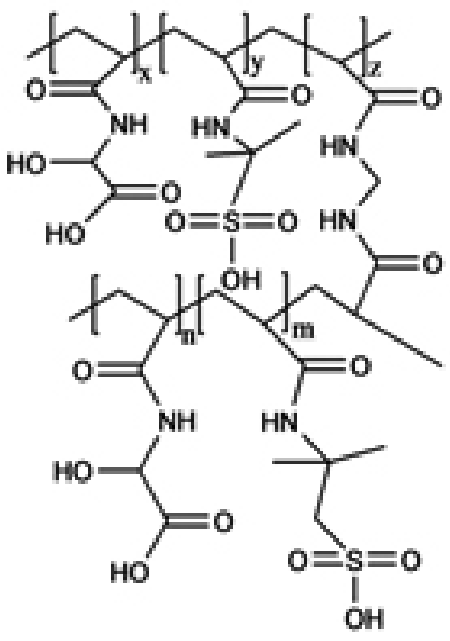

c)

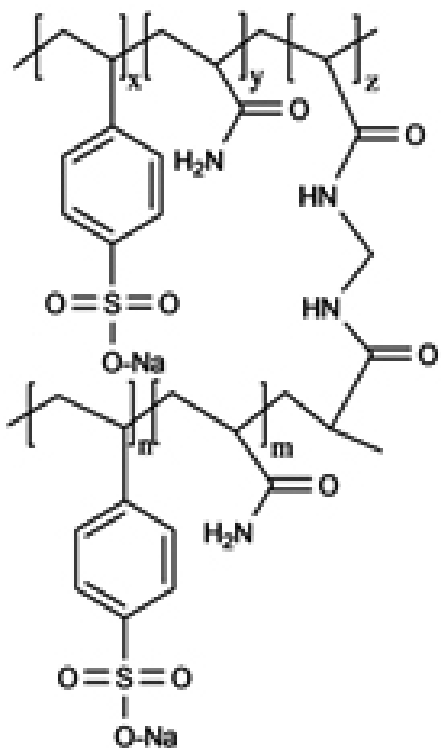

P(AAGA-co-APSA), and P(AAGA-co-ESS) resins were synthesized on a laboratory scale by radical polymerization using acrylamide and the hydrated sodium salt of 4-styrenesulfonate acid monomers for the P(AAm-co-ESS) resin,2-acrylamidoglyolic monohydrate acid and acrylic acid monomers for the P(APSA-co-AAc) resin,2-acrylamidoglyolic monohydrate acid and 2-acrylamide-2-methyl-1-propanesulfonic acid monomers for the P(AAGAco-APSA) resin, and 2-acrylamidoglyolic monohydrate acid and the hydrated sodium salt of 4-styrenesulfonate acid for the P(AAGA-co-ESS) resin. N,N'methylene-bis-acrylamide ( $4 \mathrm{~mol} \%$ ) was used as the crosslinking reagent, and $1 \mathrm{~mol} \%$ of ammonium persulfate was used as the initiator. All of the reagents were introduced into a polymerization flask with $10 \mathrm{~mL}$ of water and were kept under a $\mathrm{N}_{2}$ atmosphere for $24 \mathrm{~h}$ at $70^{\circ} \mathrm{C}$. The resins were then filtered, washed with distilled water, and finally dried in an oven at $40^{\circ} \mathrm{C}$ until a constant weight wasachieved. After that, the resins were ground and sieved to obtain particle sizes of $250 \mu \mathrm{m}, 180 \mu \mathrm{m}$, and $100 \mu \mathrm{m}$. The experiments used the 250-180 $\mu \mathrm{m}$ fraction. The general structure of P(AAm-co-ESS), P(APSA-co-AAc), $\mathrm{P}$ (AAGA-co-APSA), and P(AAGA-co-ESS) resins are shown in Figure 1.a-d, respectively

b)

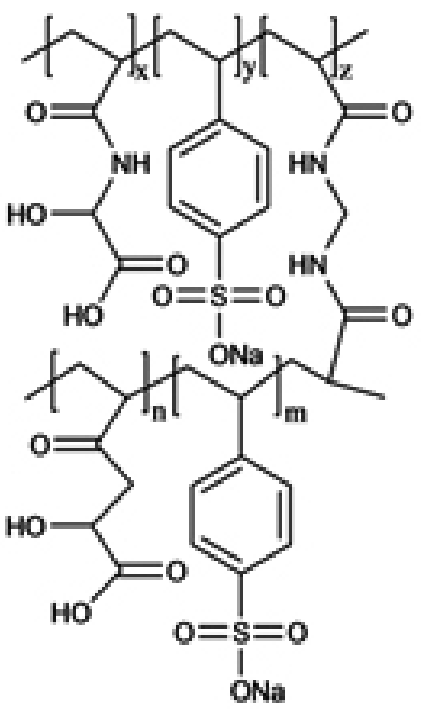

d)

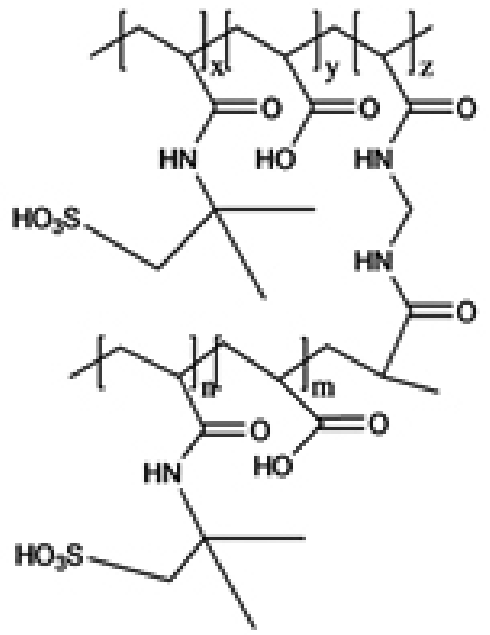

Figure 1.Structures of (a) $\mathrm{P}(\mathrm{AAGA}-c o-A P S A)$, (b)P(AAGA-co-ESS), (c) P(AAm-co-ESS), (d) P(APSA-co-AAc) resins 


\section{Instrumentation}

A JEOL JSM-6380 LV scanning electron microscope wasused to observe the morphology of the ion exchange resins. A Magna Nicolet FT-IR spectrometer 550 was employed to identify the typical absorption signals of the functional groups of the ion exchanger. An Ezodo P1-600 digital pH meter was used to adjust the solution $\mathrm{pH}$; and a Varian Spectra AA200 atomic absorption spectrometer was used for $\mathrm{Cr}$ analysis.

Characterization

The P(AAm-co-ESS), P(APSA-co-AAc), P(AAGA-co-APSA), and $\mathrm{P}$ (AAGA-co-ESS) resins were characterized by FT-IR spectroscopy over the range of 400 to $4000 \mathrm{~cm}^{-1}$ to identify the typical absorption signals of the exchange groups on the resins.

Degree of swelling

One hundred milligrams of dry resin and $80 \mathrm{~mL}$ of bidistilled water were introduced and kept in a $100 \mathrm{~mL}$ beaker for $24 \mathrm{~h}$ to evaluate the degree of swelling. Once the residence time was completed, the beaker contents were filtered and the wet resin was weighed to obtain the mass of water absorbed per gram of resin (Eq.(1)).

$$
\text { Degree of swelling }=\frac{\text { Wet mass of resin }}{\text { Dry mass of resin }}
$$

The resins can be classified as (a) xerogel ( $0 \mathrm{~g} \mathrm{H}_{2} \mathrm{O} / \mathrm{g}$ resin), (b) hydrogel (0-100 $\mathrm{g} \mathrm{H}_{2} \mathrm{O} / \mathrm{g}$ resin), and (c) superabsorbent (higher than $100 \mathrm{~g} \mathrm{H}_{2} \mathrm{O} / \mathrm{g}$ resin).

Metal ion adsorption

A batch equilibrium procedure was applied to determine the metal ion binding ability of the synthesized resins. All the experiments were performed in a flask mounted on a shaker at $25^{\circ} \mathrm{C}$. For all the experiments, the polymers with particle sizes of 180-250 $\mu \mathrm{m}$ were used.

To find the optimal amount of resin for Cr(III) removal, $0.005,0.01,0.02$, 0.04 , and $0.08 \mathrm{~g}$ of resin was contacted with $25 \mathrm{~mL}$ of $20 \mathrm{mg} / \mathrm{L} \mathrm{Cr}$ (III) solution at $\mathrm{pH} 3.62,25^{\circ} \mathrm{C}$, and a stirring speed of $70 \mathrm{rpm}$ for $24 \mathrm{~h}$.

For the elution study, $0.1 \mathrm{~g}$ of each resin was contacted first with $50 \mathrm{~mL}$ of $20 \mathrm{mg} / \mathrm{L} \mathrm{Cr}$ (III) at $\mathrm{pH} 3.62$ for $\mathrm{Cr}(\mathrm{III})$ sorption. During the elution step, each

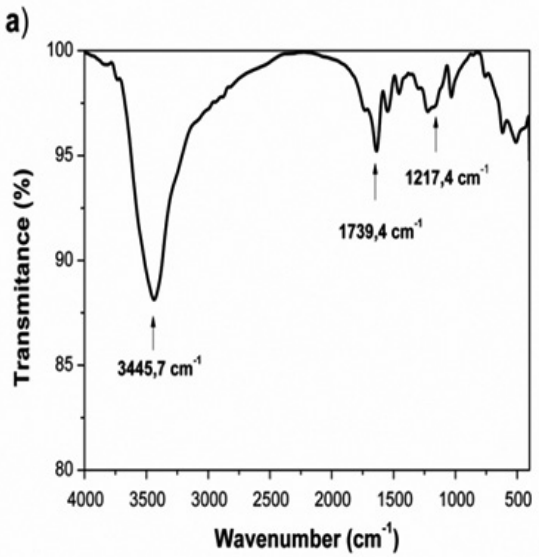

c)

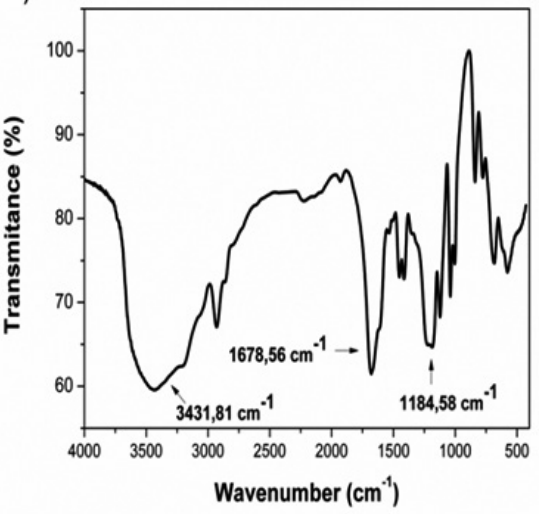

resin was contacted with $50 \mathrm{~mL}$ of $1.0,2.0$, and $4.0 \mathrm{~mol} / \mathrm{L} \mathrm{HCl}$ for $24 \mathrm{~h}$ at $25^{\circ} \mathrm{C}$. This procedure was carried out separately for each acid (1.0, 2.0 and $4.0 \mathrm{~mol} / \mathrm{L}$ $\mathrm{HCl}$ with the metal loaded resin).

The kinetic studies were carried out using $0.4 \mathrm{~g}$ or $1.2 \mathrm{~g}$ of resin and 750 $\mathrm{mL}$ of the $\mathrm{Cr}(\mathrm{III})$ solution $(20 \mathrm{mg} / \mathrm{L}$ of $\mathrm{Cr}(\mathrm{III}))$ at $25^{\circ} \mathrm{Cin}$ a water bath with mechanical stirring at $250 \mathrm{rpm}$.

The column study was performed using $0.5 \mathrm{~mL}$ of resin packed inside a glass column with a $0.7 \mathrm{~cm}$ internal diameter. A Cr(III) solution of $20 \mathrm{mg} / \mathrm{L}$ of $\mathrm{Cr}$ (III) was passed through the column with a flow rate of $15 \mathrm{~h}^{-1}$ (space velocity, $(\mathrm{SV}), \mathrm{L}($ solution $/ \mathrm{h}) / \mathrm{L}$ resin). The effluent fractions $(5.0 \mathrm{~mL})$ were collected by a fraction collector.

$2 \mathrm{~mol} / \mathrm{L} \mathrm{HCl}+0.5 \mathrm{~mol} / \mathrm{L} \mathrm{NaCl}+\mathrm{H}_{2} \mathrm{O}_{2}$ mixture was used for the elution of $\mathrm{Cr}$ (III) from the resin with a flow rate of $5 \mathrm{~h}^{-1}$. The analysis of $\mathrm{Cr}$ (III) was performed with a Varian atomic absorption spectrometer.

\section{RESULTS AND DISCUSSION}

\section{Synthesis of resins}

The water-insoluble resins containing carboxylic acid, sulfonic acid, and amido groups of P(AAGA-co-APSA), P(AAGA-co-ESS), P(AAm-co-ESS), and $\mathrm{P}(\mathrm{APSA}-\mathrm{co}-\mathrm{AAc})$ were obtained by radical copolymerization of equivalent mole ratios of the co-monomers. The yields for these resins were $87.8 \%$ for $\mathrm{P}$ (AAGA-co-APSA), $86.3 \%$ for P(AAGA-co-ESS), and $100 \%$ for P(AAm-coESS) and P(APSA-co-AAc). The structures are shown in figure 1.a-d.

Sorption of $\mathrm{Cr}(\mathrm{III})$ is due to the existence of the main functional groups (carboxylic and sulfonic acids) attached to polymers through the ion exchange reactions.

Characterization

The P(AAGA-co-APSA), P(AAGA-co-ESS), P(AAm-co-ESS), and $\mathrm{P}(\mathrm{APSA}-\mathrm{co}-\mathrm{AAc})$ resins were characterized by FT-IR spectroscopy over the range of $400-4000 \mathrm{~cm}^{-1}$ to identify the typical absorption signals of the resin exchange groups.

Figure 2 shows the corresponding FTIR spectra of the synthesized resins, and Table 1 summarizes the most important signals in those spectra.

b)

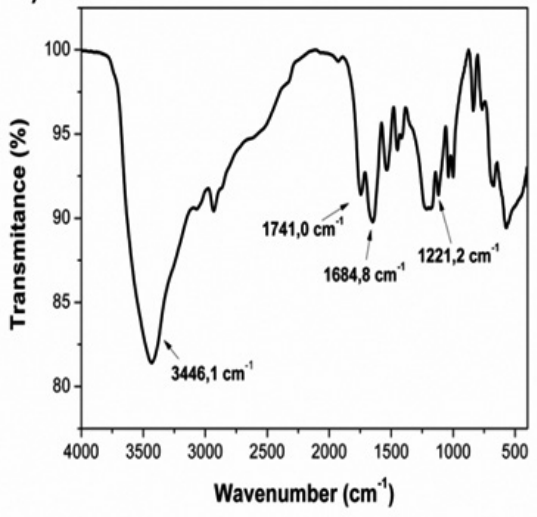

d)

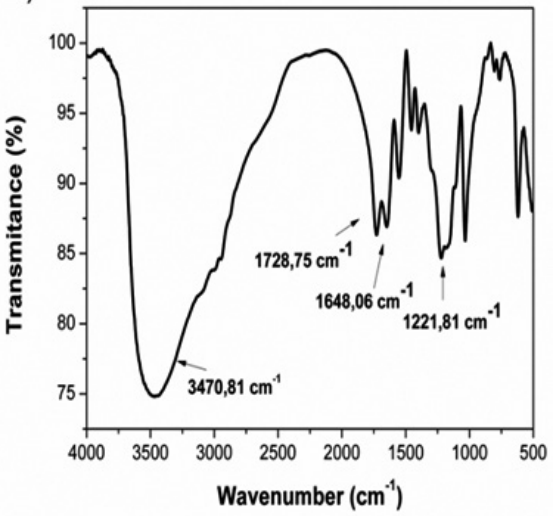

Figure 2. FTIR spectra of: (a) P(AAGA-co-APSA), (b) P(AAGA-co-ESS), (c) P(AAm-co-ESS), and (d) P(APSA-co-AAc) resins. 
Table 1. Summary of the more characteristic FT-IR absorption signals.

\begin{tabular}{|c|c|c|c|c|}
\hline & Signal & $\left(\mathrm{cm}^{-1}\right)$ & & \\
\hline Resin & $\mathrm{OH}$ & $\mathrm{NH}-\mathrm{C}=\mathrm{O}$ & $\mathrm{C}=\mathrm{O}$ & $\mathrm{S}_{3} \mathrm{O}_{3} \mathrm{H}$ \\
\hline P(AAGA-co-ESS) & 3446.1 & 1684.8 & 1741.0 & 1221.2 \\
\hline P(AAGA-co-APSA) & 3445.7 & 1739.4 & 1739.4 & 1217.4 \\
\hline P(AAm-co-ESS) & 3431.8 & 1678.5 & 1678.5 & 1184.5 \\
\hline P(APSA-co-AAc) & 3470.8 & 1648.1 & 1728.7 & 1221.8 \\
\hline
\end{tabular}

\section{Degree of swelling (DS)}

The ability to swell is one of the most important properties of ion exchange materials. Almost all ion exchange reactions involve an internal solution of the exchanger. Another important property is the nature of the ion exchange groups, and in this case, both resins contain hydrophilic carboxylic and sulfonic acid groups with high affinities for water.

For this study, resins between 180 and $250 \mu \mathrm{m}$ were used. The resins demonstrated high water absorption capacities, thus, the pores of the resins opened large enough to allow the sufficient diffusion of water into the resins. According to the results of this study, the synthesized resins are hydrogel-type resins: $15.87 \mathrm{~g} \mathrm{H}_{2} \mathrm{O} / \mathrm{g}$ resin for P(AAGA-co-APSA), $10.35 \mathrm{~g} \mathrm{H} \mathrm{O} / \mathrm{g}$ resin for $\mathrm{P}\left(\mathrm{AAGA}-\mathrm{co}\right.$-ESS); $8.26 \mathrm{gH}_{2} \mathrm{O} / \mathrm{g}$ resin for $\mathrm{P}\left(\mathrm{AAm}-\mathrm{co}\right.$-ESS) and $10.21 \mathrm{~g} \mathrm{H}_{2} \mathrm{O} / \mathrm{g}$ resin $\mathrm{P}(\mathrm{APSA}-\mathrm{co}-\mathrm{AAc})$.

Effect ofresin amount for $\mathrm{Cr}$ (III) removal (Equilibrium study)

As seen in figure 3 , all the resins synthesized showed a high removal capacity of $\mathrm{Cr}(\mathrm{III})$ at $\mathrm{pH} 3.62$. All the resins removed greater than $90 \%$ of the $\mathrm{Cr}(\mathrm{III})$ at $1.0 \mathrm{mg} / \mathrm{L}$.

The optimal amount of resin for $\mathrm{Cr}(\mathrm{III})$ removal for each resin was $1.5 \mathrm{mg}$ resin/L solution. The removal of $\mathrm{Cr}(\mathrm{III})$ with $\mathrm{P}(\mathrm{AAGA}-$-co-APSA) was $89.4 \%$,while the respective value for P(AAGA-co-ESS)was $88.3 \%$. Additionally, P(AAm-co-ESS) exhibited a Cr(III) removal of $86.8 \%$ and P(APSA-co-AAc) removed $89.3 \%$.

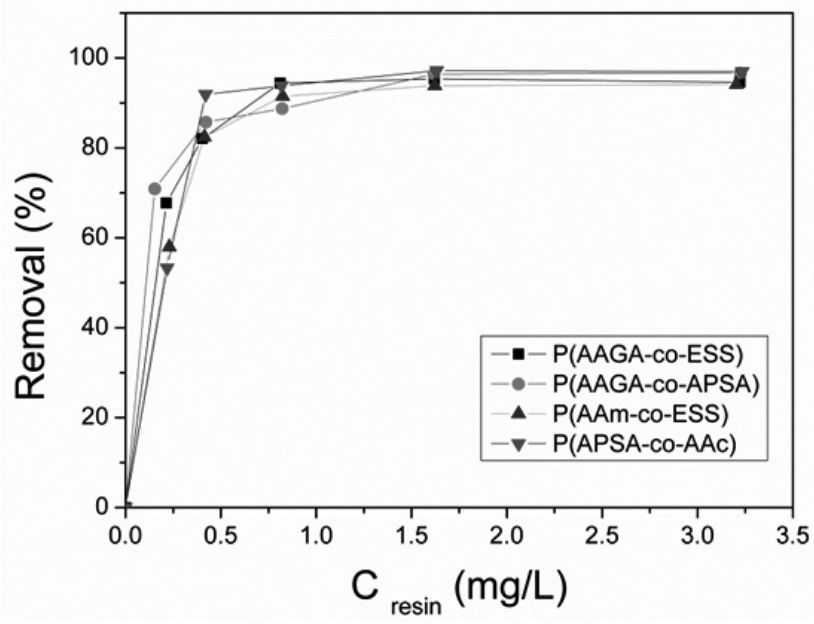

Figure 3.Removal (\%) of $\mathrm{Cr}(\mathrm{III})$ vs. resin dosage at $\mathrm{pH} 3.62$.

\section{Batch elution}

To see the effect of $\mathrm{HCl}$ concentration on the elution performance of P(AAGA-co-APSA) resin for $\mathrm{Cr}(\mathrm{III})$, a series of batch elution tests was performed following batch sorption of $\mathrm{Cr}(\mathrm{III})$. Table 2 shows the results.

It was possible to elute $\mathrm{Cr}(\mathrm{III})$ from $\mathrm{P}(\mathrm{AAGA}-\mathrm{co}-\mathrm{APSA})$, resin using a 2 $\mathrm{mol} / \mathrm{L} \mathrm{HCl}$ solution with a high elution efficiency $(90.3 \%)$.

Table 2. Batch elution for P(AAGA-co-APSA).

\begin{tabular}{|c|c|c|c|}
\hline & Adsorbed (mg) & Eluted (mg) & Removal (\%) \\
\hline 1 & 1.1265 & 0.9805 & 87.0 \\
\hline 2 & 1.1377 & 1.0270 & 90.3 \\
\hline 4 & 1.1370 & 1.0585 & 93.1 \\
\hline
\end{tabular}

Kinetic performance of resins

The kinetic models are a good method for describing the adsorption process, and demonstrate the transport of the metal ions inside of the resin. The kinetic data obtained for the ion exchange resins fit to sorption kinetics using pseudo-first order and pseudo-second order kinetic models. The results are shown in Table 4.

The resin $\mathrm{P}(\mathrm{AAGA}-\mathrm{co}$-APSA) reached equilibrium after $20 \mathrm{~min}$ with 91.8\% Cr(III) removal, while P(AAGA-co-ESS) resin reached equilibrium after 45 min with $90.5 \% \mathrm{Cr}(\mathrm{III})$ removal. As shown in figure 4, the polymers $\mathrm{P}(\mathrm{AAm}-\mathrm{co}$-ESS) and $\mathrm{P}(\mathrm{APSA}-\mathrm{co}-\mathrm{AAc})$ reached equilibrium after $30 \mathrm{~min}$ with $100 \%$ removal.
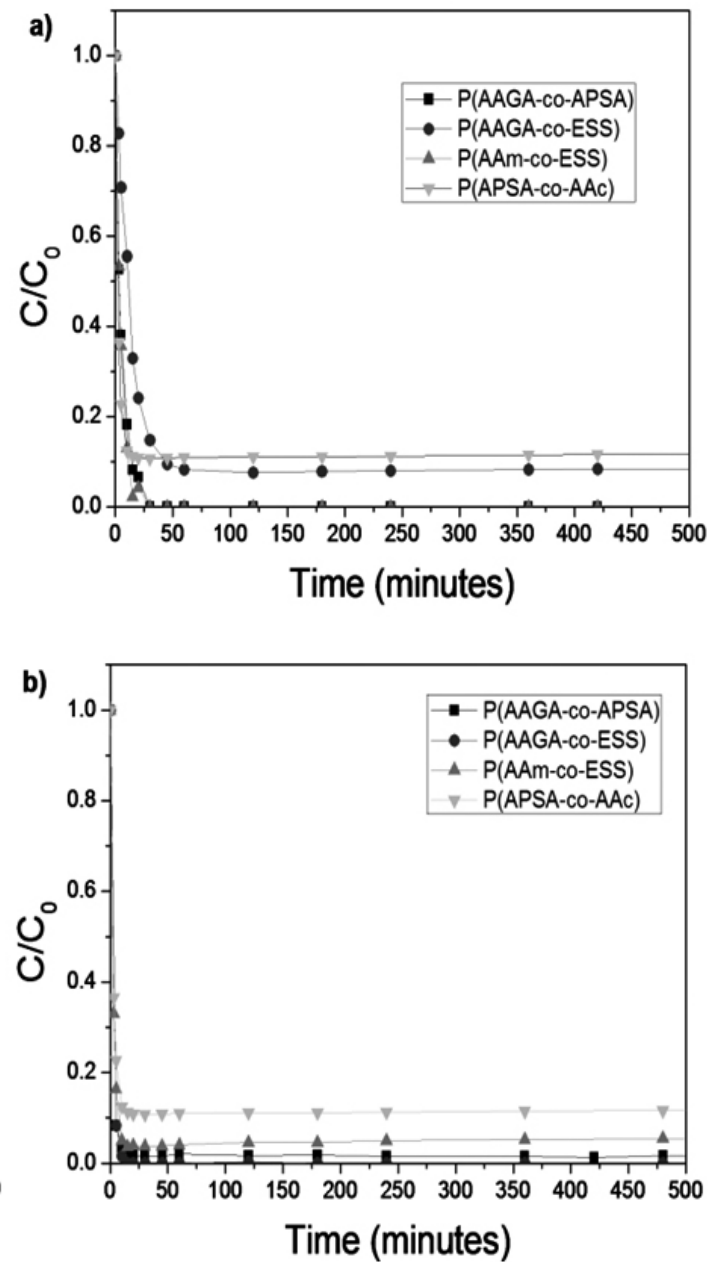

Figure 4.Kinetic profiles of the ion exchange resins at $\mathrm{pH} 3.62$ (a) $0.4 \mathrm{~g}$ of resin, and (b) $1.2 \mathrm{~g}$ of resin.

To predict the mechanism involved in the adsorption process, several different kinetic models are used including Lagergren pseudo-first and pseudosecond order, the Elovich equation, and the parabolic diffusion model. Among these, the sorption kinetics were usually described by pseudo-first or pseudosecond order models [23].

The sorption kinetics following the pseudo-first-order are given by:

$$
\frac{d q}{d t}=k_{1}\left(q_{e}-q_{t}\right)
$$

$q_{t}$ : Amount of adsorbed species $(\mathrm{mg} / \mathrm{g})$ at time $\mathrm{t}$.

$q_{e}$ : Amount of adsorbed species (mg/g) at equilibrium time.

$k$ : Adsorption rate constant $\left(\mathrm{min}^{-1}\right)$.

Integrating Eq. (2) with respect to the following boundary conditions: $q=0$ at 0 , and $q=$ at $q$ at $t=t$, one obtains 


$$
\log \left(q_{e}-q_{t}\right)=\log \left(q_{e}\right)-\frac{k_{1}}{2.303}
$$

The adsorption rate constant $\left(\mathrm{min}^{-1}\right)$ can be calculated from the plot of $\left(q_{e}-q_{t}\right)$ versus time.

The kinetics data can be analyzed via pseudo-second-order kinetics:

$$
\frac{d q}{d t}=k_{2}\left(q_{e}-q_{t}\right)^{2}
$$

$\mathrm{k}_{2}$ : Pseudo-second order rate constant ( $\left.\mathrm{g} / \mathrm{mg} \min \right)$

$q_{t}$ : Amount of adsorbed species ( $\mathrm{mg} / \mathrm{g}$ ) at time $\mathrm{t}$.

$q_{e}$ : Amount of adsorbed species $(\mathrm{mg} / \mathrm{g})$ at equilibrium time. Substituting the variables in Eq. (4) one gets

$$
\frac{d q}{\left(q_{e}-q_{t}\right)^{2}}=k_{2} d t
$$

and integrating Eq. (5) for the following boundary conditions:

$t=0$ to $t=t$, and $q=$ and $q=0$ and $q=\mathrm{q} e$, one obtains the final form

$$
\frac{t}{q_{t}}=\frac{1}{k_{2} q_{e}^{2}}+\frac{1}{q_{e}} t
$$

A plot of versus gives the value of the constants ( $\mathrm{g} / \mathrm{mg} \mathrm{min})$, from which it is possible to calculate $(\mathrm{mg} / \mathrm{g})$.

The ion exchange between the counterion in the solution and the exchangeable ion at the active site on the resin occurs in a heterogeneous process. Mass transfer models are based upon the following steps in the process [24] :

Transport of the exchanging ions from bulk solution to the outer surface of the resin particle.

1. Diffusion through a film/boundary layer at the external surface of the particle.

2. Pore diffusion of the ions to the active sites.

3. Actual exchange process (chemical reaction).

4. Pore diffusion of the ions outward through the particle from the active sites.

5. Back diffusion through the film/boundary layer at the particle surface.

6. Transport of the exchanged ions from the external surface of the resin particle to the bulk solution.

The overall rate of the ion exchange process is determined by the relative rates of these steps. Usually, the resistance in the bulk solution (1 and 6) is easily controlled and negligible. The kinetic studies on ion exchange separation consider only three resistances, therefore, the exchange rate can be controlled by film diffusion ( 2 and 6 ), particle diffusion ( 3 and 5) and the chemical reaction (4).

The kinetics data fit to diffusion models as given in Table 3, according to the unreacted core model (UCM) and infinite solution volume (ISV).

Table 3. Diffusion and reaction models.

\begin{tabular}{|c|c|c|}
\hline Method & Equation & Rate controlling step \\
\hline ISV & Where & Film diffusion \\
\hline & Where & Particle diffusion \\
\hline UCM & & Liquid film \\
\hline & & Reacted layer \\
\hline & & Chemical reaction \\
\hline
\end{tabular}

Figure $4 \mathrm{a}$ shows the kinetic profiles of the synthesized resins $(0.4 \mathrm{~g}$ of resin/750 mL Cr(III)). It was possible for P(AAGA-co-APSA), P(AAm-coESS), and P(APSA-co-AAc) resins to remove higher than $90 \%$ of $\mathrm{Cr}(\mathrm{III})$ in 20 $30 \mathrm{~min}$, while P(AAGA-co-ESS) required $45 \mathrm{~min}$. Figure $4 \mathrm{~b}$ shows the kinetic profiles for the synthesized resins using $1.2 \mathrm{~g}$ of resin/750 $\mathrm{mL} \mathrm{Cr}(\mathrm{III})$. It was possible for P(AAGA-co-APSA), P(AAGA-co-ESS), and P(AAm-co-ESS) resins to remove greater than $95 \%$ of the $\mathrm{Cr}(\mathrm{III})$ in $10 \mathrm{~min}$, whereas P(APSAco-AAc) resin removed almost $90 \%$ of $\mathrm{Cr}$ (III) in $20 \mathrm{~min}$.

The mechanism that control de adsorption process, was evaluated according to Lagergren pseudo-first and pseudo-second order kinetic model, when the linear correlation coefficients were compared, it was observed that adsorption kinetics for $\mathrm{P}(\mathrm{AAGA}-\mathrm{co}-\mathrm{APSA})$ and $\mathrm{P}$ (APSA-co-AAc) resins agreed well with a pseudo-second order mechanism, while the P(AAGA-coESS $)$ and $\mathrm{P}(\mathrm{AAm}-\mathrm{co}$-ESS $)$ resin kinetics agreed well with a pseudo-first order mechanism. The mechanism of pseudo-second-order suggest a chemisorption. The adsorption kinetic depends on the number of $\mathrm{Cr}(\mathrm{III})$ ions on the surface of the resin and the number of $\mathrm{Cr}$ (III) ions at the equilibrium[25-29],meanwhile the mechanism of pseudo-first order suggest that the race is proportional to the initial concentration of $\mathrm{Cr}$ (III) [30].

The kinetics data were also evaluated using diffusion and reaction models to find the rate determining steps for the resins, in table 3 are shown the different models. In Table 4, the linear correlation coefficients are given. According to the UCM model, the rate is controlled by the reaction layer for the P(AAGA-coAPSA) and P(APSA-co-AAc) resins, and chemical reaction for the P(AAGAco-ESS) and $\mathrm{P}(\mathrm{AAm}-\mathrm{co}$-ESS) resins. According to the ISV model, the rate determining step is film diffusion (diffusion through a film/boundary layer at the external surface of the particle / back diffusion through the film/boundary layer at the particle surface) for the P(AAGA-co-APSA), P(AAGA-co-ESS) and $\mathrm{P}(\mathrm{APSA}-\mathrm{co}-\mathrm{AAc})$ resins, whereas it is particle diffusion (pore diffusion of the ions to the active sites / pore diffusion of the ions outward through the particle from the active sites)for the $\mathrm{P}(\mathrm{AAm}-\mathrm{co}$-ESS) resin[31].

Table 4. Summary of kinetic models.

\begin{tabular}{|c|c|c|c|c|}
\hline & $\begin{array}{c}\text { P(AAGA- } \\
\text { co-APSA })\end{array}$ & $\begin{array}{c}\text { P(AAGA- } \\
\text { co-ESS })\end{array}$ & $\begin{array}{c}\text { P(AAm- } \\
\text { co-ESS })\end{array}$ & $\begin{array}{c}\text { P(APSA- } \\
\text { co-AAc) }\end{array}$ \\
\hline First order & 0.8821 & 0.9841 & 0.9668 & 0.9703 \\
\hline Second order & 0.9848 & 0.7895 & 0.9130 & 0.9812 \\
\hline Film diffusion & 0.9999 & 0.9922 & 0.8721 & 0.9703 \\
\hline Particle diffusion & 0.9736 & 0.9602 & 0.9327 & 0.9436 \\
\hline Liquid film & 0.8969 & 0.8168 & 0.9155 & 0.7663 \\
\hline Reacted layer & 0.9837 & 0.9895 & 0.9072 & 0.9953 \\
\hline Chemical reaction & 0.8623 & 0.9948 & 0.9234 & 0.9691 \\
\hline
\end{tabular}

Column adsorption

The column study was performed only with the P(AAGA-co-APSA) resin to remove $\mathrm{Cr}(\mathrm{III})$ from a model solution $(20 \mathrm{mg} \mathrm{Cr}(\mathrm{III}) / \mathrm{L})$ at $\mathrm{pH} 4.0$. The breakthrough profile curve is shown in figure 5. The column data for the P(AAGA-co-APSA)resin are summarized in Table 5 for the first and second cycles.

The P(AAGA-co-APSA) resin exhibited a high breakthrough capacity of $1.5 \mathrm{mg} \mathrm{Cr}(\mathrm{III}) / \mathrm{mL}$ resin at a breakthrough point of $70.8 \mathrm{BV}$ for cycle I. However, the breakthrough point shifted to $61.8 \mathrm{BV}$ in the second cycle, with a breakthrough capacity of $1.2 \mathrm{mg}$ of $\mathrm{Cr}(\mathrm{III}) / \mathrm{mL}$ resin. The total capacity of the P(AAGA-co-APSA) resin for $\mathrm{Cr}$ (III) was $5.2 \mathrm{mg}$ of $\mathrm{Cr}(\mathrm{III}) / \mathrm{mL}$ resin in the first cycle, which decreased to $4.8 \mathrm{mg}$ of $\mathrm{Cr}(\mathrm{III}) / \mathrm{mL}$ resin in the second cycle.

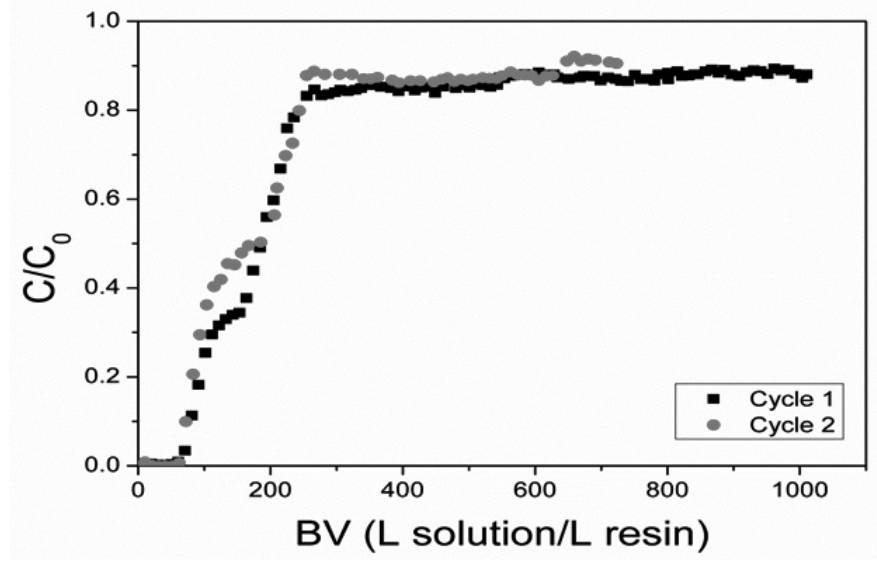
$\mathrm{pH} 4$ 
As seen from table 5, the elution of $\mathrm{Cr}$ (III) in cycle I was not completed using only a $2 \mathrm{~mol} / \mathrm{L} \mathrm{HCl}$ solution, which was not strong enough for continued use in this method. The $\mathrm{Cr}$ (III) adsorbed on the resin was considered to have partly converted to a perfectly insoluble form of $\mathrm{Cr}$ (III) overtime. Therefore, following acid elution, the resin was eluted with $0.5 \mathrm{~mol} / \mathrm{L} \mathrm{NaOH}+1 \mathrm{~mol} / \mathrm{L}$ $\mathrm{H}_{2} \mathrm{O}_{2}$ mixture to oxidize $\mathrm{Cr}$ (III) to $\mathrm{Cr}(\mathrm{VI})$ and complete the elution. The total elution efficiency in cycle I was almost $100 \%$ when the $0.5 \mathrm{~mol} / \mathrm{L} \mathrm{NaOH}+$ $1 \mathrm{~mol} / \mathrm{L} \mathrm{H}_{2} \mathrm{O}_{2}$ mixture was used following elution with $2 \mathrm{~mol} / \mathrm{L} \mathrm{HCl}$. In the second cycle, the elution efficiency was $90.2 \%$ with only the $0.5 \mathrm{~mol} / \mathrm{L} \mathrm{NaOH}$ $+1 \mathrm{~mol} / \mathrm{L} \mathrm{H}_{2} \mathrm{O}_{2}$ mixture.

Table 5. Column data for $\mathrm{Cr}(\mathrm{III})$ removal with P(AAGA-co-APSA).

\begin{tabular}{|c|c|c|}
\hline Cycle & I & II \\
\hline Breakthrough Point (BV) & 70.8 & 61.8 \\
\hline Breakthrough Point Cr(III) Concentration (mg/L) & 0.7 & 0.1 \\
\hline Breakthrough Capacity (mg Cr / mL-resin) & 1.5 & 1.2 \\
\hline Total Capacity (mg Cr / mL-resin) & 5.2 & 4.8 \\
\hline Column Utilization (\%) & 29.3 & 26.8 \\
\hline Adsorption of $\mathrm{Cr}(\mathrm{III})$ (mg) & 2.93 & 2.4 \\
\hline Elution of $\mathrm{Cr}$ (III) with $2 \mathrm{~mol} / \mathrm{L} \mathrm{HCl}$ (mg) & 1.78 & - \\
\hline $\begin{array}{l}\text { Elution of } \mathrm{Cr}(\mathrm{III}) \text { with } 0.5 \mathrm{~mol} / \mathrm{L} \mathrm{NaOH}+1 \mathrm{~mol} / \mathrm{L} \\
\qquad \mathrm{H}_{2} \mathrm{O}_{2}(\mathrm{mg})\end{array}$ & 0.96 & 2.2 \\
\hline Elution Efficiency with $2 \mathrm{~mol} / \mathrm{L} \mathrm{HCl}(\%)$ & 69.1 & - \\
\hline $\begin{array}{l}\text { Elution Efficiency with } 0.5 \mathrm{~mol} / \mathrm{LNaOH}+1 \mathrm{~mol} / \mathrm{L} \\
\qquad \mathrm{H}_{2} \mathrm{O}_{2}(\%)\end{array}$ & 37.2 & 90.2 \\
\hline Total Elution Efficiency (\%) & $100 \pm 6$ & 90.2 \\
\hline
\end{tabular}

\section{CONCLUSIONS}

The ion exchange resins $\mathrm{P}(\mathrm{AAGA}-\mathrm{co}$-APSA), P(AAGA-co-ESS), $\mathrm{P}(\mathrm{AAm}-\mathrm{co}$-ESS), and $\mathrm{P}(\mathrm{APSA}-\mathrm{co}-\mathrm{AAc})$ were successfully synthesized with greater than $86 \%$ yield. The infrared spectra demonstrated that the functional groups of the resins were carboxylic and sulfonic acids for the P(AAGA-coAPSA), P(AAGA-co-ESS), and P(APSA-co-AAc) resins, and sulfonic acid and amide groups for $\mathrm{P}(\mathrm{AAm}-\mathrm{co}-\mathrm{EES})$. According to the degree of swelling, $\mathrm{P}(\mathrm{AAGA}-\mathrm{co}$-APSA), P(AAGA-co-ESS), P(AAm-co-EES), and P(APSA-coAAc) are hydrogels.

The ion exchange resins P(AAGA-co-APSA), P(AAGA-co-ESS), $\mathrm{P}(\mathrm{AAm}-\mathrm{co}$-EES), and $\mathrm{P}(\mathrm{APSA}-\mathrm{co}-\mathrm{AAc})$ showed a high removal capacity for $\mathrm{Cr}$ (III). The P(AAGA-co-APSA) resin exhibited faster kinetics than the others, following a mechanism of pseudo-second-order, that suggest chemisorption. According to UCM and ISV models the rate is controlled by reaction layer and the determining rate step is film diffusion.

The P(AAGA-co-APSA) resin exhibited a high sorption capacity for $\mathrm{Cr}(\mathrm{III})$ and very good elution efficiency during the column-mode study.

In general, the ion exchange process has demonstrated to be an adequate method to remove inorganic contaminants like another ion removal processes [32-37].

\section{ACKNOWLEDGMENTS}

The authors thank FONDECYT (Grant No 1150510) and the7FP-MC Actions Grant CHILTURPOL2 (PIRSES-GA-2009 Project, Grant No 269153) for financial support.

\section{REFERENCES}

1. Andrei A. Zagorodni (2007) Ion Exchange Materials: Properties and applications, first edition.

2. C. E. Harland (1994) Ion Exchange: Theory and practice, second edition

3. Çavus S. and Gürdag G.(2008)Competitive heavy metal removal by poly(2-acrylamido-2-methyl-1-propane sulfonic acid-co-itaconic acid). Polym. Adv. Technol. 19:1209-1217.

4. Urbano B. F. and Rivas B. L. (2013) Synthesis, characterization, and sorption properties of water-insoluble poly(2-acrylamido-2-methyl-1propane sulfonic acid-co-sulfonic acid)- montmorillonite composite.
Polym. Bull. 70:1143-1162.

5. Rivas B. L., Muñoz, C., Leiton, L. and Pooley S. A. (2011) Metal ion removal properties of crosslinked poly(acrylamide-co-2-acrylamide-2methyl-1-propane sulfonic acied). J. Appl.Polym. Sci.120:586-591.

6. Rivas B. L., Martínez E., Pereira E. and Geckeler, K. E.(2001)Synthesis, characterization and polychelatogenic properties of poly[(2-acrylamido2-methyl-1-propane sulfonic acid)-co-(methacrylic acid)].Polym. Int.50:456-462.

7. Bajaj P., Paliwal D. K. and Gupta, A. K. (1993) Acrylonitrile-acrylic acids copolymers. I. Synthesis and characterization.J. Appl. Polym. Sci. 49:823833.

8. Rivas B. L., Peric I. M.; Muñoz C. andAlvear, R. (2012)Poly(Nhydroxymethyl acrylamide-co-acrylic acid) and poly( $N$-hydroxymethyl acrylamide-co-acrylamidoglycolic acid): synthesis, characterization, and metal ion removal properties. Polym. Bull. 68:391-403.

9. Urbano B. F. and Rivas B. L. (2012)Poly(sodium 4-styrene sulfonate) and poly(2-acrylamido glycolic acid) polymer-clay ion exchange resins with enhanced mechanical properties and metal ion retention.Polym. Int.61:2329.

10. Travas-Sejdic, J. and Easteal, A., (2000) Study of free-radical copolymerization of acrylamide with 2-acrylamido-2-methyl-1-propane sulphonic acid. J. Appl. Polym. Sci.75:619-628.

11. Rivas B. L., Muñoz C. (2007) Removal of environmentally impacting metal ions using functional resin poly(4-styrene sulfonate-co-4-vinylpyridine): Synthesis and metal ion retention properties. J. Appl.Polym. Sci.104:17691774.

12. Santander I. P., Rivas B. L., Urbano B., Leiton, L., Y1lmaz İpek, İ., Yüksel M., Kabay N. and Bryjak, M. (2014) Removal of Cr(VI) by a chelating resin containing N-methyl-D-glucamine. Polym. Bull.71:1813-1825.

13. Hasnat A. and Juvekar V. A. (1996) Ion exchange Kinetics: Heterogeneous Resin-Phase Model.AIChE J. 42:161-175.

14. World Health Organization(2011) Guidelines for drinking-water quality, four edition, Switzerland.

15. Chromium (III) and its inorganic compounds (2009) The Mak Collection for occupational Health and Safety, value Documentations.

16. Li H., Li J., Chi Z. and Ke W. (2012)Kinetic and equilibrium studies of chromium (III) removal from aqueous solution by IRN-77 cation-exchange resin. Proc. Env. Sci. 16:646-655.

17. Licinio M. Gando-Ferreira (2012) Ion Exchange Technology II: Applications, 323-336.

18. Petruzzelli D., Liberti L., Passino R. and Tiravanti G. (1990) Recent Developments in Ion exchange, Part 5, 265-275.

19. Kocaoba S., Aksin G., Monatsh.A (2008) kinetic investigation of removal of chromium from aqueous solutions with a strong cation exchange resin. Chem.139:873-879.

20. Alguacil J.F., García-Diaz, I., Lopez F. (2012) The removal of chromium (III) from aqueous solution by ion exchange on Amberlite 200 resin:Batch and continuous ion exchange modeling. Desalin.Water Treat.45:55-60.

21. Morales D. V., Rivas B. L. (2014) Poly(acrylamide-co-styrene sodium sulfonate) and Poly(2-acrylamide-2-methyl-1-propane sulfonic acid-coacrylic acid) resins with removal properties for $\mathrm{Hg}(\mathrm{II}), \mathrm{Pb}(\mathrm{II}), \mathrm{Cd}(\mathrm{II})$ and Zn(II).J. Chil. Chem. Soc. 49 (N'2) 2420-2526.

22. Morales D. V., Rivas B. L. (2015) Poly(2-acrylamidoglycolic acidco-2-acrylamide-2-methyl-1-propane sulfonic acid) and Poly(2acrylamidoglycolic acid-co-4-styrene sodium sulfonate): synthesis, characterization and properties for use in the removal of $\mathrm{Cd}(\mathrm{II}), \mathrm{Hg}(\mathrm{II})$, $\mathrm{Zn}(\mathrm{II})$, and $\mathrm{Pb}(\mathrm{II})$. Polym. Bull. 72 (2) 339-352.

23. Demircioğlu M., Kocacık N., Yiğit E. and Kabay N. (1998) Innovations in mineral and coal processings 781-785.

24. Kabay N., Sarp S., Yüksel M., Arar Ö., Bryjak M. (2007) Removal of boron from seawater by selective ion exchange resins. React. Funct. Polym.67:1643-1650.

25. Justi K. C., Fávere V. T., Laranjeira M.C. M., Neves A., Peralta R. A (2005) Kinetics and equilibrium of $\mathrm{Cu}(\mathrm{II}), \mathrm{Cd}(\mathrm{II})$ and $\mathrm{Ni}(\mathrm{II})$ by chitosan functionalized with 2[-bis(pyridylmethyl aminomethyl]-4-methyl-6formylphenol. J. Colloid Interf. Sci.291:369-374.

26. Chen Q., Zhou K., Chen Y., Wang A., Liu F. (2017) Removal of ammonia from aqueous solution by ligand exchange onto a $\mathrm{Cu}(\mathrm{II})$-loaded chelating resin: Kinetics, equilibrium and thermodynamics. RSC Adv.7:1281212823.

27. Sheng G., Hu J., WhangX. (2008) Sorption properties of Th(IV) on the raw diatomite-Effect of contact time, $\mathrm{pH}$, ionic strength and temperature. Appl. Radiation Isotopes 66:1313-1320. 
28. Saruchi Kumar V. (2016) Adsorption Kinetics and isotherms for the removal of rhodamine $\mathrm{B}$ dye and $\mathrm{Pb}^{2+}$ ions from aqueous solutions by hybrid ion-exchanger.Arabian J. Chem. 1-14.

29. Siu P.C.C., Koong L. F., Saleem J., BarfordJ., Mckay G. (2016) Equilibrium and Kinetics of cooper ions removal from wastewater by ion exchange. Chin. J. Chem. Eng.24:94-100.

30. Guo H., Rhen Y., Sun X., Xu Y., Li X.,Zhang T., Kang J., Liu D. (2013) Removal of $\mathrm{Pb}^{2+}$ fromaqueous solution by a high-efficiency resin. Appl. Surf. Sci.238:660-667.

31. Ozkula G., Urbano B. F., Rivas B. L., Kabay N., Bryjac M. (2016) Arsenic sorption using mixtures of ion Exchange resins containing N-methyl-Dglucamine and quaternary ammonium groups. J. Chil. Chem. Soc. $61\left(\mathrm{~N}^{\circ} 1\right)$ 2752-2756.

32. Rivas B.L., Pooley S.A., Pereira E., Cid R., Luna M.,Jara M.A. Geckeler KE. (2005). Water-soluble amine and imine polymers with ability to bind metal ions in conjunction with membrane filtration. J. Appl.Polym. Sci.96:
222-231.

33. Rivas B.L., Moreno-Villoslada I. (2000) Prediction of the retention values associated to the ultrafiltration of mixtures ions and high molecular weight water soluble polymers as a function of the initial strength $J$. Membrane Sci. 178:165-170

34. Geckeler K.E, Zhou R., Rivas B.L. (1992) Metal Complexation of Poly1(2 hydroxyethyl)aziridine-co-2-methyl-2-oxazoline in aqueous solution. Angew. Makromol. Chem.197: 107-115.

35. Rivas B.L., Maturana H.A., Pereira E. (1994) Metal Ion Binding Properties of Vinyl Synthetic Resins. Angew. Makromol. Chem. 220: 61-74.

36. Rivas B.L., Maturana, H.A, Catalán R.E., Perich I.M. (1989) Branched and Linear Poly(ethyleneimine) Supports for Resins with Retention Properties for Copper and Uranium. Part 7. J. Appl. Polym. Sci. 38: 801-807.

37. Rivas B.L., Pereira E. (2000) Obtention of Poly(allylamine)-Metal Complexes through Liquid-Phase Polymer Based Retention (LPR) Technique. Bol. Soc. Chil. Quím. 45: 165-171- 